\title{
EXPRESSION OF THE NEEDS OF THE CHARACTERS OF FAIRY TALES CREATED BY CHILDREN GROWING UP IN FAMILIES AT SOCIAL RISK AND THEIR SATISFACTION
}

\author{
Nijolė Bražienè \\ Vilnius University Šiauliai Academy, Lithuania
}

\begin{abstract}
The scientific literature analyses in detail the problems of a family at social risk, threats to the child's social and personality development, etc., however, all insights are provided from an adult perspective - research that would allow the voice of a child growing up in a family at social risk to be heard has not been detected. Children have a limited ability to talk about their experiences. This is facilitated by the creation of a fairy tale, where the child, through the images of the characters created, can safely convey his/her individual life experiences. The aim of the article is to identify the expression of the needs of the characters of fairy tales created by children growing up in families at social risk and their satisfaction. Fairy tales created by 9-12 year old children were selected as the object of analysis. Of the 69 texts written by children, 47 were selected for analysis. The content analysis of fairy tales was based on the principles of phenomenological hermeneutics. The analysis of fairy tales created by children growing up in families at social risk shows that the characters of the fairy tales they create experience the following unmet needs: physiological, security and social. Heroes of the fairy tales of children growing up in families at social risk are not prone to solving problems, it is more comfortable for them to live as usual, although not always they feel good because of that.
\end{abstract}

Keywords: children's voice, child's needs, fairy tale created by a child, family at social risk, middle childhood.

\section{Introduction}

In many countries, as the attitude towards children changes and children are perceived as a social group with a certain social status, there is an increasing focus on childhood research and various research from a child's perspective (e.g., Tangen, 2008; Maybin, 2012; Tay-Lim \& Lim, 2013; Livesley \& Long, 2013; Nimante et al., 2018; Rouvali \& Riga, 2018; Malinauskienè \& Juodaitytė, 2019; Urbina-García, 2019). Such research takes place focusing on the situation of the child's being in the present and allows to get to know the child's real experiences. 
The socialization of an individual in society takes place in different conditions, which are characterized by one or another danger that negatively affects human development. As a result, groups of people, who become victims of unfavourable circumstances of socialization, emerge. These include children growing up in families at social risk. Researchers (e.g., Masiliauskienè \& Griškutė, 2010; Dobelniece et al., 2015; Gudzinskiene \& Augutavicius, 2018) point out that families at social risk are characterized by a variety of problems of poverty, alcohol abuse, violence, unemployment, poor housing and other problems. Most of the problems are related to poor basic skills or lack of them, also to lack of motivation to change. Children growing up in such a family face poverty, primitive value orientation, a negative psychological climate and upbringing mistakes. When such a stressful environment prevails, the child develops a wrong attitude both towards himself/herself and others - as a result, children from families at social risk try to distance themselves from the environment, not to trust those around them. The scientific literature analyses in detail the problems of a family at social risk, threats to the child's social and personality development, etc., however, all insights are provided from an adult perspective - research that would allow the voice of a child growing up in a family at social risk to be heard has not been detected.

Children have a limited ability to talk about their experiences. This is facilitated by the creation of a fairy tale, where the child, through the images of the characters created, can safely convey his/her individual life experiences, attitudes to the surrounding environment and at the same time talk about worrying problems and imaginary solutions to them. The aim of the article is to identify the expression of the needs of the characters of fairy tales created by children growing up in families at social risk and their satisfaction.

According to S. Broström (2002), the stories created by children also exhibit each child's growing awareness of his/her environment and life concerns, these are texts, which, as I. Zandere (2007) states, "best reflect a modern child's encounter with everyday reality and how he/she perceives, evaluates, catalogues, and mythologizes that reality (...). It is an authentic document" that helps adults to look at the phenomena of the child's world from the child's perspective.

\section{Methodology}

Fairy tales created by children aged 9-12 years, i.e., in middle childhood $(\mathrm{N}=69)$, have been chosen as the object of the article. The research was conducted in the academic year 2019-2020 in seven day care centres of the Lithuanian town X. (A children's day care centre is an institution of social services, the purpose of which is to provide day care, occupation, leisure time 
organization, etc. services for children, materially and morally weak families in order to normalize their relationships with the social environment.) The research was organized in accordance with L. Karlsson's (2013) principles of the organization of the creative process of a fairy tale, focused on the child's right to be listened to, heard and understood, and the provisions on respect for the child's opinion.

The researcher met with small groups (3-5 children), having arranged the meeting in advance with the administration of the day care centres and obtained the consent of the children's parents (guardians) to communicate with their children. Children's participation was based on the principles of voluntary participation, free self-determination and confidentiality. Each meeting began with a conversation about reading, a favourite book, a tale, or a story. The conversation ended with the researcher's introduction that she is interested in fairy tales created by children, collects and analyses them, therefore, she knows that everyone has unique thoughts that allow them to create interesting stories. The children were then invited to take part in a study - to create and write their own fairy tale. Instructions for creating a fairy tale were not provided - the children had a right to decide for themselves which characters, which place and time of the action to choose, how to construct the plot. After finishing writing the fairy tale, the children decided for themselves whether they wanted to read aloud what they had created (or they wanted the researcher to read it aloud), or whether they agreed to give their fairy tales (or copies) to the researcher.

Although writing should be one of the most enjoyable, valuable, and effective tools for creative self-expression and self-discovery, as G. Rodari (2001) and V. Oaklander (2007) notice, children do not like writing. This is mainly due to the fact that children do not have good writing skills, moreover, they have some experience that when evaluating their creative works at school, the first emphasis is on spelling, form, sentence structure, handwriting - it inhibits and impedes the child's creative flow of thoughts, discourages the desire to create a story. Therefore, it was especially important for children to hear that the researcher adheres to the attitude that the author's own fairy tale is excellent and interesting as it is, that the researcher will not correct or mark mistakes in texts created by them, will not pay attention to clumsy handwriting, will not tell them to rewrite the fairy tale, will not limit the time of creating a fairy tale children will decide for themselves how much and how they want to correct and improve their creative task. In this way, each child was given the power to decide what and how he/she wanted to write, and the researcher took on only the role of an understanding reader.

Of the 69 texts written by children, 47 were selected for analysis, i.e., those in which elements of the fairy tale genre can be seen. The fairy tales created by 
the children were analysed using content analysis; the principles of phenomenological hermeneutics, focused on the disclosure of meanings constructed in children's authentic texts, were relied on, avoiding the researcher's prejudices, interpretations and limiting to highlighting the commonalities related to the expression of the needs of fairy tale characters.

To make the expression of the needs of the characters of the fairy tales created by children growing up in families at social risk more visible, the context of fairy tales created by children in middle childhood growing up in the middle and higher social class families was used to compare the main themes of these texts and the peculiarities of the development of the plot (Bražienè, 2018). The article presents authentic children's texts - only spelling and punctuation errors have been corrected, sentence boundaries have been clarified (for the convenience of translating from Lithuanian into English); children's names have been changed.

\section{Background}

Fairy tales created by children in the context of a narrative. A. Preece (1987), who studied the ability of 5-7 year old children to create stories in a conversational stream, distinguished 14 types of narratives. In addition to the usual narratives from experience, retelling of an event seen or heard, etc., stories of original fiction are indicated. They include texts where one can see originality and novelty as far as possible, where events are associated with fantasy characters. As B. Sutton-Smith (1981) notices, the structure in children's stories is in accordance with the structure of the folk tales. Thus, it is no coincidence that in children's stories of original fiction distinguished by A. Preece (1987), the traditional features of the fairy tale genre (beginning and end formulas, environment, props, characters) are sought, it is considered whether the texts created by children contain a complicated situation, a difficult task, and so on. Therefore, the type of original fantasy narrative singled out by A. Preece (1987) is similar to the traditional fairy tale of miracles. A. Preece essentially responds to the features of fairy tales created by children highlighted by A.N. Applebee (1978). According to A.N. Applebee (1978), a fairy tale created by a child is a story composed of a chain of events, framed by traditional beginning and end formulas, it depicts extraordinary events, a conflict situation, and fantasy characters act in an unusual space of action.

One of the most necessary and important elements of any fairy tale mentioned by both A. Preece (1987) and A.N. Applebee (1978) - conflict or the culmination of a fairy tale - can be different in fairy tales created by children. According to the assessment of E. Maranda and K. Maranda (1971), in fairy tales created by children, one can see four levels of conflict resolution (stories 
that do not have any of the following ways of conflict resolution are attributed to zero level):

1. No resistance. These are rather primitive plots where one force defeats another without the latter even trying to resist. Usually, texts of this type are limited to the information that the hero is threatened, the villain defeats the hero, the lack is identified or what is lost is indicated. In rare cases, the villain is presented, the evil done is described.

2. Unsuccessful reaction. The hero tries to resolve the conflict, but the idea fails. Sometimes the hero simply escapes, and sometimes the villain suddenly "converts" - becomes favourable.

3. Quick success. The hero reduces the danger relatively easily and quickly, or nullifies it altogether; achieves what was lacking. Often the threat is eliminated or the task is solved through the mediation of helpers.

4. Successful transformation. This is a part of the plot development close to traditional miracle tales. The lack is liquidated by the hero's personal efforts, experience, wisdom or through the mediation of helpers, through miraculous means.

According to E. Maranda and K. Maranda (1971), the fantasy narratives of children at the end of early childhood are usually dominated by the first and second levels of conflict resolution, meanwhile, the fourth one - successful transformation - is noticed in the plots of the stories created by girls in middle childhood. However, boys of the same age rarely choose a successful transformation. Most likely it is related to the style of conflict resolution: the hero of the plots created by boys defeats the villain by force or cleverness, meanwhile, girls rely more on forming an alliance. Moreover, the characters of the fairy tales created by boys are more physically active. Thus, it determines that boys create more dynamic and interesting plots than girls, in the boys' stories there is the explicit - and usually enthusiastic - depiction of active violence, conflict, and destruction (Sutton-Smith, 1981; Nicolopoulou, 2011).

Due to the fact that fairy tale texts written by children are created following the example of traditional miracle fairy tales, scholars (Sutton-Smith, 1981; Broström, 2002; Nicolopoulou, 2011) suggest evaluating them according to the system of functions, i.e., characters' deeds significant to the action of the fairy tale, formulated by V. Propp (see more Propp, 1968). G. Rodari (2001) points out that each function of a fairy tale resonates in the child's individual world and helps the child to understand himself/herself, as the structure of the fairy tale is in some ways related to the structure of the child's experience, which necessarily involves a sequence of tasks and struggles, severe trials and 
disappointments. The child has the experience of interdiction, miraculous gifts, miraculous donors, his/her world is inhabited by powerful allies and fierce enemies.

From the above, it can be stated that children in middle childhood, creating their fairy tale, need to be able to: begin/end the text with traditional beginning/end formulas; compose a text from a chain of unexpected events, trying to use as many elements of the traditional fairy tale as possible; the text must contain a clear conflict situation and its resolution in a new and unique way, construct the plot using the functions of a fairy tale. If the listed elements are not present in the created text, consequently, it is not a fairy tale, but only a story.

The context of social and personality development in middle childhood. Middle childhood is an intense time for a child's personality development. In this period, individual differences of the child, determined by nature and social environment, become apparent. Middle childhood is a period of time when the perception of personal competence is the main theme of social and personality development. According to G. Halász \& A. Michel (2011), personal competence is defined as the integrity of the person that in relations with others and oneself is expressed in the person's dignity, self-confidence, responsibility for one's actions, self-esteem, commitment to meaningful goals and the ability to pursue them. As J. Eccles (1999) states, personal competence is determined by three key forces: (1) cognitive changes that heighten children's ability to reflect on their own successes and failures; (2) a broadening of children's worlds to encompass peers, adults, and activities outside the family; and (3) exposure to social comparison and competition in school classrooms and peer groups (p. 33). Every child's experience in the context of communication is influenced by emotional and behavioural reactions that vary depending on personality, selfawareness, and relationships. According to E. Erikson's theory (Erikson, 2004), middle childhood is described as a period of the industry-inferiority crisis. At this stage of development, children develop an understanding of their abilities the child's self-esteem depends on both real achievements (the one who is more successful evaluates himself/herself better, the one who is less successful evaluates himself/herself worse) and the assessment of those around him/her. Children, like adults, want to be respected, loved, want to communicate, understand others, and so on. If these needs are not met, an inferiority complex emerges, accompanied by such unpleasant feelings as fear, guilt, anger, which can turn into aggression, and so on. According to A. Maslow's theory (Maslow, 2006), of the hierarchy of needs, the emergence of higher needs (esteem and self-actualization) is conditioned by the satisfaction of physiological and security needs, in addition to which, the social needs that determine the child's 
socialization are important. Without having satisfied the lowest - physiological and security - needs, a person does not care about the higher ones.

In middle childhood, according to J. Eccles (1999), H. Gazelle \& M.J. Druhen (2009), relationships with peers and related emotional experiences are very important for children. However, here, along with the likelihood of being popular and attractive to his/her peers, the child is at risk of being rejected by peers and feeling lonely. Rejection of peers or the disappointment of the child himself/herself with friends can increase anxiety and reduce the child's selfesteem. Children, who are rejected by peers and excluded from joint activities become socially helpless, always expect rejection and do not try to seek new relationships, initiate new social contacts. Moreover, according to the aforementioned authors, although middle childhood is a period when a child is increasingly striving for independence and wants to be independent of the family, attachment to parents is still important.

One of the most important goals of parents when raising children is to meet their needs, i.e., physical, cognitive, social, moral and spiritual needs. Many authors (cit. Kondrotaite, Butvilas, 2007) note that in families at social risk emotional communication is impaired, such families are unable to meet the child's emotional and physical needs, moreover, the way they communicate significantly limits the child's opportunities to develop appropriate social skills, express his/her necessary needs and feelings. The most important characteristics of the individuals of the lower stratum are reticence, reconciliation with the current situation and insufficient initiatives to change that situation, as well as inadequate regulation of relations when problems are resolved through conflict and force. E. Masiliauskienė \& V. Griškute (2010) identified the consequences of parental misconduct for children growing up in families at social risk: failure to ensure the physical, mental, spiritual and moral development and safety of children; the environment created in the family is unfavourable for the healthy and productive growth and development of the child; children are characterized by unfavourable self-esteem; children have not acquired the necessary social skills; fundamental rights (care, education, etc.) of children are not realized; children's opportunities to participate in the life of society, grow and develop spiritually are restricted. When one grows up in such conditions, a wrong attitude towards the world and oneself is formed. This is what makes one distance oneself from the social environment, not trust those around. Children growing up in such families have very low self-esteem, do not expect that their needs are important and can be met. 


\section{Research Results}

Comparing the fairy tales created by children in middle childhood growing up in families that are not at social risk and in families at social risk, it has been observed that the texts created by the latter children have a very simple plot, are close to a simple story, fairy tales lack the development of the action, moreover, the characters' goals, desires, motives of behaviour are not always clearly perceived, the causal connections of the characters' actions are not understandable, the presentation of events lacks consistency and completeness, there is a lack of fantasy elements typical of the fairy tale genre, there is a little use of the functions of a fairy tale. The most common functions used in the fairy tales of children growing up in families at social risk - lack, departure from home, meeting the Donor, liquidation of lack, arrival home. The fairy tales of children growing up in families at social risk do not have magical agents, interdiction, violation of the interdiction, transference of the hero to the whereabouts of an object of search, difficult tasks and their solutions, functions of the hero's transfiguration - i.e., such functions that are present in the fairy tales of children growing up in families that are not at social risk. The ways of liquidation of lack/conflict resolution also vary: the fairy tales of children growing up in families at social risk are dominated by the first two levels of conflict resolution singled out by E. Maranda \& K. Maranda (1971) - "no resistance" and "unsuccessful reaction", in several fairy tales "quick success" has been identified. The fourth level - "successful transformation" - has not been found in any of the fairy tales. It can be said that the fairy tales of children growing up in families at social risk meet the criteria by which foreign researchers distinguish five-year-old children's fairy tales from other types of narrative.

Nevertheless, in general, the themes of the fairy tales of children in middle childhood growing up both in families that are not at social risk and in families at social risk are very similar - the plots are dominated by the aspects of communication between family members and relationships between children. However, attention is drawn to the fairy tales of children growing up in families at social risk, which by name were assigned to the theme of happiness (e.g., "Happiness”, "The Spring of Happiness”, “The Happy Man”, “The Happy Day of Miracles”, "The Girl's Happiness”). Fairy tales of children growing up in families that are not at social risk with such names have not been observed. As can be deduced from the texts created by children, happiness is usually understood by the authors of fairy tales as meeting the physiological needs that determine a person's chances of survival. 


\section{The Spring of Happiness}

Once upon a time there lived poor people. They had no money, no food to eat and nowhere to sleep at night. Once they saw a spring. People came up to that spring to drink. And that spring says, "Come up with two wishes!" The first wish was to have a place to live, the second to have money. All the wishes were fulfilled. Since then, they have lived long and happily (Rita, 11).

\section{The Happy Day of Miracles}

Once upon a time, a good princess lived in a slum. She did not have nice clothes and delicious meals. One day she was picking apples and saw a large house. It was her house. She went inside. Everything was beautiful there. A few hours later, a lot of beautiful clothes, all kinds of shoes appeared in her room. And then all sorts of delicious meals appeared. The girl thought that today was a happy day of miracles. She lived well and happily (Rima, 10).

Both when reading these and other fairy tales of an analogous plot, the position of the authors stands out that the "happiness" of having something to eat, where to live, what to wear, as if should be given, donated by someone, received effortlessly - just unexpectedly. Only the creators of two fairy tales seem to understand the reason why their characters live badly - you have to work to have something, to be able to buy something, e.g.: (...) the old man asks, "Do you want to earn money?" "And what work will I have to do?" "Pasture the sheep and then I will give you food and money." "No, old man, don't even dream, pasture them yourself!" (...) The third brother met the same old man, did what the old man asked. He got a lot of food, money and came back joyful. The whole family ate well, bought a new house and lived happily ever after (Romas, 11); (...). The eldest sister went out to look for work. She met an old man. He says, "Where are you going, girl?" "None of your business!", the maid retorted angrily. (...). A few days later, the maid came back without money. The parents ask, "So why didn't you earn anything?" "Because I didn't find a job!" (...) Then the youngest sister left. "Hello, girl, where are you going?" "To look for a job, we ran out of money!" (...) The maiden went home with her salary. (...) Left money and lived a long and happy life (...) (Toma, 12).

Although these fairy tales are created referring to the example of a folk tale, it would be wrong to say that this was the easiest path chosen by the authors to construct their fairy tale. According to childhood researcher A. Juodaitytè (2002), "the actions, thoughts, thinking and activity structures of a particular child, as well as the cognitive operations performed are discovered by them independently, and not blindly copied and taken from the environment" ( $\mathrm{p}$. 197). Consequently, the behaviour of the hero of the folk tale, based on responsibility, morality, service, honesty, etc., and the consequence of that behaviour - the award - were probably the discovery of the child himself/herself, an experience taken from the folk tale and possibly verified in real life, transformed in an alternative form in his/her own fairy tale. On the other hand, in fact, there is an understandable reason why the heroes of fairy tales are passive in liquidating the lack of unmet physiological needs - it is the duty of adults to take care of it. Perhaps due to this fact, reading the fairy tales of 
children growing up in families at social risk, the impression is that meeting physiological needs does not require as much effort from the heroes as meeting social needs. This, according to the plots of the fairy tales, depends on the hero's interaction with family, peers and school and is a necessary condition for the hero's adaptation to the environment and survival.

The plots of the fairy tales on the family theme created by children growing up in families at social risk are quite diverse. In the fairy tales created on this topic by children growing up in families that are not at social risk, there is an evident competition between siblings for parents' attention, the fear of losing one's parents, meanwhile, in the fairy tales of children growing up in families at social risk, the following plot lines are distinguished: the desire to live in their biological family, adoption and the conviction that you are unnecessary to anyone.

The child's need - happiness to live in his/her family and feel loved there is illustrated by the fairy tale "The Girl's Happiness":

\section{The Girl's Happiness}

Once upon a time there lived a girl. Dad and mum didn't love her. The day came when she decided to escape, and she did. When the girl escaped, she went in search of happiness. She reached a huge lake, and there she met a sorcerer. The sorcerer asked her, "Where are you going, girl?" "I ran away from home," she replied and went on. But the sorcerer stopped her and said, "If you want, I can fulfil two of your wishes." "Really?" the girl asked. "Really," he replied. "I want to be loved by everyone and come home." "Okay." She happily returned home (Roma, 11).

It has been observed that often in a fairy tale of children growing up in a family at social risk, conflict situations arise due to the unmet need of parents' love and attention - fairy tale characters in the family feel unnecessary, unloved, shouted at, beaten, therefore, the only way out is to run away from home. However, they soon start to miss homes, parents, and look for ways to be with their family members again, e.g.: (...). The boy wanted to return to his mother. (...) he told that he wanted to return to his beloved family, to his village. He longed for his family, the village, his yard and garden so much (...) (Arūnas, 10); (...) The child told the king that he had run away from home, now he wants to return, but does not remember the way. (...) (Šarūnas, 11); (...). That child had no parents. And the king began to look for them. Five years later, those parents were found and invited to the kingdom to take the child. (...) (Ramune, 9).

If, in the fairy tales quoted, their heroes return to their biological family in one way or another and continue to live happily, in some children's fairy tales lack is immediately named - the main character has no family. In such cases, the authors of the fairy tales solve the problem by finding a new family, and in all cases, that of the king, e.g.: (...). The boy told the king that he had no family. The king presented him with a book. The boy became happy and allowed him to be adopted. (...) (Sigitas, 9); (...). The king tells him, "Maybe you want a new home? I have no doubt that someone would want a child like you. Would you like to live with me? You would be a great son to the king." The child replied, "I would be very grateful to you." (Ligita, 10); (...).The 
king hired a guard to go in search of the girl's home, mother and father. And went out to look for her parents. They visited many houses, but no one was her parents. (...). She stayed with the king. They lived happily and did not quarrel (Brigita, 11).

However, not all children's heroes would agree to live with guardians. This is evidenced by an excerpt from the fairy tale of Ramūnas (11): (...) When Jonukas grew up a little bit older, the king wanted to adopt him, but he refused. (...) When it was night and everyone was asleep, Jonukas packed his things and ran away from home. The king did not worry and did not tell to look for him.

It is not clear how Jonukas' story would unfold, however, what is most worrying are the words of the author of the fairy tale that "the king did not worry and did not tell to look for him". There is a thought that it seems to the authors of fairy tales of a similar plot that other characters are indifferent to their characters, that you cannot feel stable in an alien environment and expect to be happy. The fear of trusting others, the belief that sometime you may become unnecessary not only in your own family, but also in a family that sheltered you can be judged from such turns of plots, e.g.: (...) His mother left him [the kitten - N. B.], when he was small, at the rubbish bin. (...) One day rich people found him. (...). And they lived long and happily. (...) One day the owners got bored with him and they left him again next to the same rubbish bin (...) There can be no good in life (Matas, 12); (...) there lived a small puppy. Some fat uncle took him to raise. (...) Then the uncle said: "Get out, stupid dog, and if you don't get out, I'll shoot you!" Rikis ran as much as he could. (...) But he no longer had the strength and died (Tadas, 12; the title of the fairy tale - "The Puppy Was and Will Be a Poor Thing”).

Fairy tales with a bad ending seem to tell about the hero's perception of the hopelessness of the current situation, the inability to find within himself/herself internal resources to change something, the loss of faith. The painful experiences of the heroes due to unmet emotional needs - security, attention, belonging, attachment - are especially felt in fairy tales, in which the author himself/herself speaks on behalf of the main character, e.g.:

\section{The Angry Tree}

Once I walked through the woods. And I saw a tree. He was beautiful. I hugged that tree. And he said angrily, "Get away from me, for I will be angry with you!" I ran home crying (Paulius, 12).

One can only guess who or what an angry tree in Paulius' fairy tale is family, peers, school, etc., but in Saule's (12) fairy tale “The Miracle”, the reason for the lack is very clear. In this fairy tale, the author apparently expresses one of the most painful personal problems - bullying at school and the need to be recognized by classmates. As can be seen from the development of the plot of the fairy tale, the heroine thinks that this cannot be achieved by her forces, maybe even impossible at all, however, hope has not been dashed yet an extraordinary mediator could change the situation. Getting such help would be the greatest miracle for the heroine. 
Bražiene, 2021. Expression of the Needs of the Characters of Fairy Tales Created by Children Growing up in Families at Social Risk and their Satisfaction

\section{The Miracle}

Once I met a fairy. I was sad. And she asks, "Why are you so sad?" And I say, "I'm very offended at school." She says, "Could I help you in some way?" The girl replied, "No one can help me." "It's possible. I will work a miracle for them to regard you as their friend." "Well, if you succeed," I said sadly. - "Well, try." And she tried. And succeeded!! I went to school and the kids say, "Oh, hello, how are you doing!?" I was very happy and said, "Finally!!" I went to that fairy and said, "You succeeded! Thank you very much!" "Well, you are welcome, be happy".

Analysing the fairy tales of children growing up in families that are not at social risk, there is a tendency observed that in their texts heroes tend to solve problems without the help of a donor, do without a magical agent (even when they have it): follow their own head, look for a way out of a difficult situation themselves, rely on their knowledge and abilities. It can be presumed that, according to A. Juodaityte (2002), it is related to the child's desire to reveal himself/herself, to the social becoming of the personality, when freedom and independence become significant for the child. The heroes of fairy tales, who are independent and capable of making decisions prove to the adult that "a child in a particular situation is (...) a creator, able to change this situation through the gained (...) experience” (ibid, p. 82). Meanwhile, the hero of the fairy tales of children growing up in families at social risk is not prone to solving problems it is good if a donor has appeared, but if there is no donor, the problem remains unsolved.

Unresolved problems are especially pronounced in fairy tales on the theme of friendship. Although a motif of the importance of peers is felt in the fairy tales, however, it cannot be said that friendship is understood by the authors of the fairy tales as a relationship based on mutual trust, e.g.:

\section{The Friends Princes Fallen Out}

Once, four princes friends were playing. They all were playing with guns. One prince hid in the fields and the others near the house. Everyone was looking for him. But they didn't find him anywhere. Two minutes later, he returned very angry. Then the two friends got into a big quarrel and started fighting. They were separated by other princes. They met a few days later but did not reconcile. Some want to play, but others don't allow them because they were very, very angry. And so they lived unhappily... (Gytis, 12).

\section{The Two Friends}

A long time ago, a newcomer moved in one beautiful summer day. The name of the newcomer was Arünas. After a while, Arünas found a friend-Linas. He was a prince and lived in the neighbouring palace. Arūnas gave Linas an apple as a little gift. But Linas did not like Arünas and insulted Arūnas. However, Arūnas did not give up and took revenge on Linas. He poured garbage into Linas' yard (Rytis, 12).

As can be seen, the word "friends" appears in the titles of both quoted fairy tales, however, only very conditionally it would be possible to attribute these texts to the topic of friendship - although it is normal to conflict, it is important to be able to tolerate negative affect, seek mutual understanding, constructively solve the problem. This has been observed in reading fairy tales created by 
children growing up in families that are not at social risk: for their authors, friendship is understood namely as a relationship based on mutual trust, when there is a conflict between friends, one not only tries to defend one's idea, but also compromises, the emotions that arise do not grow into uncontrollable outbursts of anger and aggression.

It could not be said that the heroes of fairy tales of children growing up in families at social risk would not want a change in their lives. The analysis of the texts revealed the motifs showing that the heroes of fairy tales try to set further goals, show initiative, but when faced with new situations, they seem confused, no longer know how to proceed, and retreat - it is more comfortable for them to live as usual, although not always they feel good because of that. This is illustrated by Edita's (12) fairy tale about the tulip:

There was such a very beautiful flower garden in the very old days. A rose and many tulips were growing there. (...) heard someone crying. Realized that one tulip was crying there. And asked, "Can I help?" And the tulip replied, "What can you help me with? I want to be a rose." (...). And the tulip turned into a rose. But it was still very bad for her. (...) Turned her into a tulip again. And so the tulip continued to envy the beauty of the rose.

It can be said that the fairy tales of children growing up in families at social risk illustrate theoretical statements about the peculiarities of social and personality development characteristic of this age period, unsatisfied or insufficiently satisfied physiological, social, emotional needs of the child. However, the most important thing is that the fairy tales of children growing up in families at social risk allow to look at the phenomena of these children's world from the child's perspective and, paraphrasing the words of D. Malinauskienè and A. Juodaityte (2019), to understand more clearly what it means to be a child in a family at social risk.

\section{Conclusions}

The fairy tales of children in middle childhood growing up in families at social risk are dominated by the themes of family relationships and relationships between children, the development of which provides information about the unsatisfied or insufficiently satisfied physiological, security and social needs of fairy tale heroes, and at the same time allows to hear the child's voice from the perspective of the authors of the fairy tales, i.e., to understand more clearly what it means to be a child in a family at social risk.

Physiological needs are among the most obvious unmet needs of the heroes of the fairy tales of children growing up in families at social risk. Although fairy tale heroes would like to live better and are very happy when living conditions improve, they do nothing for their own well-being - their well-being is taken 
care of by an accidentally encountered magical agent or helper or better living conditions, money appears as if by itself. The impression is that, according to the understanding of the authors of the fairy tales, having something to eat, where to live, what to wear, as if should be given, donated by someone, received effortlessly - just unexpectedly.

In fairy tales on the theme of the family, unmet security and social needs are evident: there is a lack of parents' love and attention, care, emotional connection - fairy tale characters in the family feel unnecessary and unloved, therefore, the only way out seen by the heroes is to run away from home. However, they soon start to miss homes, parents, and look for ways to be with their family members again.

In cases when the main character has no family, the authors of the fairy tales find him/her a new family (and in all cases, that of the king), where the hero of the fairy tale feels happy. However, not all the heroes of the fairy tales would agree to live with guardians - some refuse to live in a new family, others run away not to be adopted. In the fairy tales of such a plot, a fear of trusting others can be seen.

In fairy tales on the theme of friendship, unmet needs for mutual understanding, friendship and recognition emerge as unsolvable problems. Although a motif of the importance of peers is felt in the fairy tales, however, the heroes of the fairy tales fail to build friendly relationships and maintain friendship - in case of conflict, the heroes fail to tolerate negative affect, do not try to solve the problem constructively, do not compromise, emotions turn into outbursts of anger and aggression.

The hero of the fairy tales of children growing up in families at social risk is not prone to solving problems - it is good if a donor has appeared, but if there is no donor, the problem remains unsolved. Perhaps because of this, the fairy tales of children growing up in families at social risk often end badly. In such plots, there is a clear perception of the hero about the hopelessness of the current situation, the inability to find within himself/herself internal resources to change something, the loss of faith. The painful experiences of the heroes due to unmet security and social needs are especially felt in fairy tales, in which the author himself/herself speaks on behalf of the main character.

In the fairy tales of children growing up in families at social risk, one can see the motifs showing that the heroes of fairy tales try to set further goals, show initiative, however, when faced with new situations, they seem confused, no longer know how to proceed, and retreat - it is more comfortable for them to live as usual, although not always they feel good because of that. This informs about the reconciliation of the heroes with the current situation and insufficient initiatives to change that situation. 


\section{References}

Applebee, A. N. (1978). The child's concept of story: ages two to seventeen. Chicago: University of Chicago Press.

Bražienè, N. (2018). Fairy World of the Texts Created by 8-11 Year Old Children. In Juodaitytè, A., Malinauskienè, D., Musneckienè, E., Bražienė, N., Lenkauskaité, J. Contemporary childhood and education of children: social-cultural contexts: Study. Šiauliai: Šiaulių universitetas, 137-186.

Broström, S. (2002). Children tell stories. European Early Childhood Education Research Journal, 10(1), 85-97. DOI: 10.1080/13502930285208861

Dobelniece, S., Millere, J., \& Salmane-Kulikovska, I. (2015). Situation analysis of social risk families with children in Latvia. Proceedings of the 2015 International Conference "Economic Science for Rural Development", 40, 141-150. Retrieved from https://llufb.llu.lv/conference/economic_science_rural/2015/Latvia_ESRD_40_2015141-150.pdf

Eccles, J. (1999). The Development of Children Ages 6 to 14. The Future of Children, 9(2), 30-44. Retrieved from https://doi.org/10.2307/1602703

Erikson, E. H. (2004). Vaikyste ir visuomene. Vilnius: Katalikų pasaulio leidiniai.

Halász, G., \& Michel, A. (2011). Key Competences in Europe: interpretation, policy formulation and implementation. European Journal of Education, 46 (3), 289-306. Retrieved from https://doi.org/10.1111/j.1465-3435.2011.01491.x

Gazelle, H., \& Druhen, M. J. (2009). Anxious solitude and peer exclusion predict social helplessness, upset affect, and vagal regulation in response to behavioral rejection by a friend. Developmental Psychology, 45(4), 1077-1096. Retrieved from https://doi.org/ 10.1037/a0016165

Gudzinskiene, V., \& Augutavicius, R. (2018). The phenomenon of social risk families and its dynamics in Lithuania. SHS Web of Conferences, 51, 03001. DOI: 10.1051/shsconf/ 20185103001

Juodaityte, A. (2002). Socializacija ir ugdymas vaikysteje. Vilnius: Petro ofsetas.

Karlsson, L. (2013). Storycrafting method-to share, participate, tell and listen in practice and research. The European Journal of Social \& Behavioural Sciences (eISSN: 2301-2218), 1109-1117. Retrieved from http://dx.doi.org/10.15405/ejsbs.88

Kondrotaitè, G., \& Butvilas, T. (2007). The socialization of children from social risk families: the analysis of experienced loss influence to their behaviour. Social Work, 6(1), 96-103. Retrieved from https://www3.mruni.eu/ojs/social-work/article/view/2073/1883

Livesley, J., \& Long, T. (2013). Children's experiences as hospital in-patients: Voice, competence and work. Messages for nursing from a critical ethnographic study. International Journal of Nursing Studies, 50(10), 1292-1303. DOI: 10.1016/ j.ijnurstu.2012.12.005

Maybin, J. (2012). Towards a sociocultural understanding of children's voice. Language and Education, 27(5), 1-15. DOI: 10.1080/09500782.2012.704048

Maranda, E., \& Maranda, K. (1971). Structural Models in Folklore and Transformational Essays. The Hague Mouton.

Masiliauskienè, E., \& Griškutè, V. (2010). Empirical research on contexts of manifestation of support provided by children day care centres for children from social risk families. 
Bražiene, 2021. Expression of the Needs of the Characters of Fairy Tales Created by Children

Growing up in Families at Social Risk and their Satisfaction

Teacher Education, 14 (1), 138-155. Retrieved from http://gs.elaba.lt/object/ elaba:6105163/6105163.pdf

Malinauskienè, D., \& Juodaitytè, A. (2019). Researcher in Childhood Research: Attitudes, Beliefs, Their Manifestation and Change. Pedagogy, 136(4), 5-16. Retrieved from https://doi.org/10.15823/p.2019.136.1

Maslow, A. H. (2006). Motyvacija ir asmenybè. Vilnius: Apostrofa.

Nimante, D., Gehtmane-Hofmane, I., \& Vasečko, L. (2018). Children's Voice and Decision Making in Institutional Care in Latvia. 11th annual International Conference of Education, Research and Innovation. Retrieved from doi: 10.21125/iceri.2018.2481

Nicolopoulou, A. (2011). Children's Storytelling: Toward an Interpretive and Sociocultural Approach. Storyworlds: A Journal of Narrative Studies, 3, 25-48. DOI: 10.1353/ stw.2011.0002

Oaklander, V. (2007). Langas i vaiko pasaulị. Kaunas: Žmogaus psichologijos studija.

Preece, A. (1987). The range of narrative forms conversationally produced by young children. Journal of child language, 14(2). Cambridge University Press, 353-373. Retrieved from https://doi.org/10.1017/S0305000900012976

Propp, V. (1968; seventeenth paperback printing, 2003). Morphology of the Folktale. Austin: University of Texas Press. Retrieved from https://monoskop.org/images/f/f3/ Propp_Vladimir_Morphology_of_the_Folktale_2nd_ed.pdf

Rodari, G. (2001). Fantazijos gramatika. Kaunas: Šviesa.

Rouvali, A. \& Riga, V. (2018). Redefining the importance of children's voices in personal social emotional development curriculum using the Mosaic Approach. Education. International Journal of Primary, Elementary and Early Years Education, 3-13, 47, 998-1013. Retrieved from https://doi.org/10.1080/03004279.2018.1553990

Sutton-Smith, B. (1981). The Folkstories of Children. University of Pennsylvania.

Tangen, R. (2008). Listening to children's voices in educational research: some theoretical and methodological problems. European Journal of Special Needs Education, 23(2), 157-166. DOI:10.1080/08856250801945956

Tay-Lim, J., \& Lim, S. (2013). Privileging Younger Children’s Voices in Research: Use of Drawings and a Co-Construction Process. International Journal of Qualitative Methods, 12(1), 65-83. Retrieved from https://doi.org/10.1177/160940691301200135

Urbina-García, M. (2019). Methodological Strategies to Listen to Children's Voices: A Systematic Critical Review. Revista Colombiana de Educación, 77, 61-85. Retrieved from https://doi.org/10.17227/rce.num77-9650

Zandere, I. (2007). Skaitančio vaiko likimas Latvijoje. Rubinaitis, 2 (42). Retrieved from http://rubinaitis.lnb.lt/index.php?3835162739 